\title{
COMPARING MEDIA CONSUMPTION: EVERYDAY LIFE IN INFORMATION SEEKING SYSTEM (ELISS) ON NAHDLATUL ULAMA AND MUHAMMADIYAH ULAMA BEHAVIOR
}

\author{
Oleh: Rama Kertamukti, Diah Ajeng P, Siantari Rihartono \\ (Dosen Ilmu Komunikasi Fakultas Ilmu Sosial Humaniora UIN Sunan Kalijaga)
}

\begin{abstract}
Intisari
Banyak hal menarik yang bisa kita teliti tentang organisasi besar di Indonesia. Studi pada perilaku informasi dari ulama di Muhammadiyah dan Nahdlatul Ulama sebagai CBO mayoritas di Indonesia dapat dilihat dari sosial dan budaya modal, nilai-nilai, komunikasi dan perilaku. Penelitian ini bertujuan untuk melihat pemenuhan kebutuhan agama dalam mencari informasi di media antara Ulama Muhammadiyah dan NU. Penelitian ini juga melihat proses aspek motivasi internal dipengaruhi pemikiran individu dan tindakan dalam pemenuhan kebutuhan religius pada kondisi bagaimana internal yang dapat dilihat dalam ekspresi yang terlihat dalam pemenuhan kebutuhan agama.

Penelitian ini dapat dikategorikan sebagai jenis penelitian kualitatif dengan lapangan (karya lapangan/penelitian) dengan pendekatan spring ethnografi. Penelitian ini mengambil karakter ulama Muhammadiyah dan Nahdlatul Ulama di wilayah Yogyakarta. Ulama Muhammadiyah dan NU bersemangat akan mencari informasi untuk memenuhi kebutuhan agamanya melalui media. Setiap individu menyadari ada persyaratan yang dipuaskan dan secara aktif mencari hal-hal yang dapat memenuhi mereka.

Ulama dan Muhammadiyah NU angka penuh semangat akan mencari informasi untuk memenuhi kebutuhan agamanya melalui media. Persyaratan adalah bahwa individu menyadari tujuan yang harus dicapai. Dalam hal ini, individu secara aktif akan mencari berbagai hal di media untuk memenuhi kebutuhan religius.
\end{abstract}

Kata kunci: eliss, konsumsi media, perilaku ulama

\begin{abstract}
A lot of interesting things that we can thoroughly about large organizations in Indonesia. Study on information behavior of ulama in Muhammadiyah and Nahdlatul Ulama as CBOs majority in Indonesia can be seen from the social and cultural capital, values, communication and behavior. This research aims to see the fulfillment of religious needs in the search for information in the media between the Scholars of Muhammadiyah and NU. the study also saw the process of internal motivation aspects influenced individual thought and action in fulfillment of religious needs up on how internal conditions which can be seen in the visible expression in the fulfillment of the needs of the religious.

This research can be categorized as a type of qualitative research with field (field works/research) with the approach of spring ethnografi. This research takes the character of ulama Muhammadiyah and Nahdlatul Ulama in the Yogyakarta region. Scholars of Muhammadiyah and NU will eagerly seek information to meet the needs of his religious through the media. Every individual is aware there is a requirement that slaked and are actively looking for things that can fulfill them.
\end{abstract}


Ulama and Muhammadiyah NU figure will eagerly seek information to meet the needs of his religious through the media. Requirement is that the individual aware of the purposes of which should be achieved. In this case, the individual will actively seek out various things in the media to meet the needs of the religious.

Keywords : eliss, media consumption, ulama behavior

\section{A. PENDAHULUAN}

Membicarakan Nahdlatul Ulama (NU) dan Muhammadiyah, ada beberapa persamaan diantara keduanya.Sementara penduduk di Indonesia, penganut agama Islam menjadi mayoritas. Meskipun jauh dari negara asal agama Islam, namun penduduk yang menganut agama Islam di Indonesia sangatlah besar, yaitu sekitar 12,7 persen dari total Muslim dunia. Indonesia merupakan negara Muslim terbesar di seluruh dunia. Pada tahun 2010, penganut Islam di Indonesia sekitar 205 juta jiwa atau 88,1 persen dari keseluruhan jumlah penduduk Indonesia saat itu.

Nahdlatul Ulama arah pergerakannya lebih mengintegrasikan Islam dengan kearifan lokal, budaya yang selama ini sudah dijalankan di Indonesia. Melanjutkan pa yang sudah dilakukan oleh Wali Songo. Seperti mengembangkan pesantren dengan membaca kitab kuning, tradisi albarjanji dan tidak menghilangkan ritual di masyarakat seperti acara kematian seperti 7 harian dan lain-lain.

Sementara Muhammadiyah lebih mengintegrasikan Islam secara modern. Arah Muhammadiyah lebih pada pengembangan sektor pendidikan dan kesehatan. Muhammadiyah bersifat lebih moderat disbanding NU yang dianggap sebagian orang masih tradisional.

Dari adanya persamaan dan perbedaan tersebut, menarik untuk mengkaji terutama mengenai perilaku ulama muhammadiyah dan NU, Utamanya dari sisi perilaku informasi. Sebagai ulama tentu mereka akan sangat bersemangat mencari informasi untuk memenuhi kebutuhan religiusnya melalui media. Kebutuhan dalam arti, bahwa individu menyadari ada keperluan yang dipuaskan dan secara aktif mencari hal yang bisa memenuhinya.

Berdasarkan ayat di bawah ini, maka prinsip-prinsip integratif yang dapat diambil adalah kebutuhan mencari informasi sesuai kebutuhan. Dalam Al-Quran surat Ali Imron ayat 190 dan Al Mujadalah ayat 11 yang tertera dibawah ini ada makna yang terkandung didalamnya bahwa manusia pada dasarnya adalah makhluk sosial. Sehingga disadari atau tidak, manusia akan selalu berinteraksi dengan sesamanya. Baik itu yang berasal dari kebudayaan yang sama atau berbeda. Dengan sifat sosialnya, manusia bisa berinteraksi untuk survive dengan keberanekaragamannya.

Dengan adanya persamaan dan perbedaan tersebut, seorang ulama muslim akan bersemangat mencari informasi untuk memenuhi kebutuhan religiusnya. Sehingga, individu akan saling membutuhkan satu sama lain walaupun berbeda organisasi massa karena menyadari ada keperluan yang harus terpenuhi. 
Diterbitkan oleh Program Studi llmu Komunikasi

Universitas Ahmad Dahlan Yogyakarta

3:190

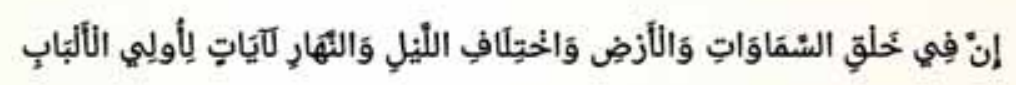

Sesungguhnya dalam penciptaan langit dan bumi, dan silih bergantinya malam dan siang terdapat tanda-tanda bagi orang-orang yang berakal,

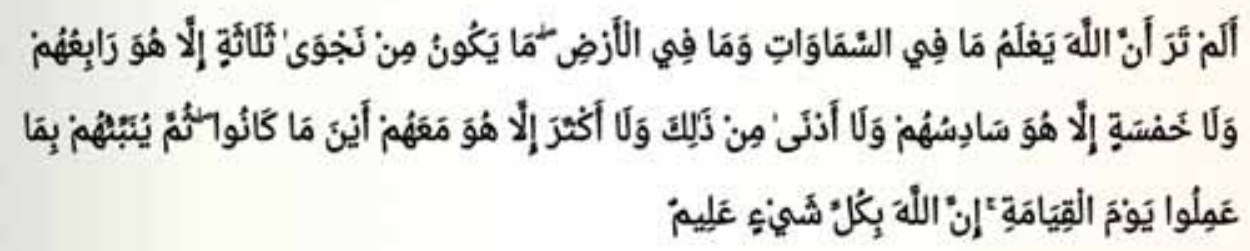

Tidakkah kamu perhatikan, bahwa sesungguhnya Allah mengetahui apa yang ada di langit dan di bumi? Tiada pembicaraan rahasia antara tiga orang, melainkan Dialah keempatnya. Dan tiada (pembicaraan antara) lima orang, melainkan Dialah keenamnya. Dan tiada (pula) pembicaraan antara jumlah yang kurang dari itu atau lebih banyak, melainkan Dia berada bersama mereka di manapun mereka berada. Kemudian Dia akan memberitahukan kepada mereka pada hari kiamat apa yang telah mereka kerjakan. Sesungguhnya Allah Maha mengetahui segala sesuatu.

Perilaku informasi ulama di Muhammadiyah dan Nahdlatul Ulama sebagai ormas mayoritas di Indonesia terutama dilihat dari modal sosial dan kultural, nilai, dan tingkah laku komunikasi. Belum banyak literatur mengenai hal ini sehingga kajian mengenai perilaku informasi ini akan sangat memperkaya kajian tersebut terutama dunia Islam dan konteks Indonesia. Rumusan masalah dalam penelitian tentang perilaku informasi ulama di Muhammadiyah dan NU dalam memenuhi kebutuhan religiusnya melalui media?

1. Faktor-faktor yang berperan ketika para Ulama akan menemukan Informasi?

2. Sumber-sumber informasi apa sajakah yang dibutuhkan para Ulama guna mem-bantu informasi ulama dalam lingkungannya yang signifikan?

3. Bagaimana tipologi penguasaan hidup Ulama ketika menemukan sumber-sum-ber informasi?

Penelitian ini dapat dikategorikan sebagai penelitian dengan jenis kualitatif lapangan (field works/research) dengan pendekatan semi ethnografi. Penelitian semi ethnografi ini berusaha untuk mendalami fenomena dari sudut pandang subyek yang diteliti sehingga di dapat pemahaman yang lebih baik akan fenomena yang diteliti. Terkait dengan hal tersebut, peneliti memberikan perhatian pada berbagai perilaku keseharian dan fenomena komunikasi yang melingkupinya sehingga dapat dideskripsikan, ditafsirkan, serta dipa- 
hami apa yang sedang terjadi dan bagaimana hal tersebut dapat terjadi (Scheibel, 2009: 6573) Untuk itu peneliti berada di lapangan untuk melakukan pengamatan serta mencermati perilaku verbal dan nonverbal subyek penelitian yang sifatnya unik dan khas dalam perilaku mencari informasi yang menjadi fokus dari penelitian ini (Baillet, 2009: 355-360). Penelitian purposive sampling mengambilnarasumber ulama Muhammadiyah dan Nahdlatul Ulama di wilayah Yogyakarta. Observasi dan wawancara akan digunakan sebagai tehnik pengumpulan data utama sesuai dengan tujuan penelitian yang ingin mendeskripsikan dengan baik dan mendalam subyek-subyek yang diteliti dalam berinteraksi dengan media dan lingkungan sekitarnya. Tehnik pengumpulan data ini juga mengacu pada jenis penelitian ethnografi yang dijadikan sebagai pegangan. Oleh karena itu pencatatan (fieldnote) menjadi sangat penting dalam pengumpulan data yang akan dilakukan. Selain daripada itu peneliti juga akan menggunakan studi dokumen sebagai pengumpulan data sekunder untuk melengkapi pengetahuan, pemahaman, serta penafsiran atas fenomena yang dicapture selama jalannya penelitian hingga akhir.

Pengolahan dan analisis data dilakukan dengan melewati proses telaah data, reduksi, abstraksi sementara, kategorisasi, dan koding secara bersamaan dalam keseluruhan proses yang dilakukan (Moleong, 2010) Seiring dengan hal tersebut, data yang ada diuraikan, diinterpretasi, dikomparasikan, serta ditriangulasi untuk mendapat keabsahan data yang telah dikumpulkan. Tujuannya adalah untuk memperoleh data yang lebih berkualitas untuk menunjukkan kondisi sesungguhnya yang terjadi di lapangan.

\section{B. KAJIAN TEORI}

\section{Teori Everyday Life Information Seeking}

Everyday Life In Information Seeking System (ELISS) adalah model yang diperkenalkan oleh Savolainen (Savolainen, 1995). Model ini berusaha keluar dari pendekatan mekanistik yang dilakukan oleh model lain dengan memberikan sejumlah faktor kualitatif seperti modal sosial dan kultural, nilai, dan tingkah laku komunikasi. Teori Everyday Life Information Seeking menekankan sifat penemuan informasi dari konteks non-work, namun hal ini tidak diartikan sebagai upaya untuk menciptakan dikotomi antara proses-proses yang berhubungan dengan informasi untuk pembagian tugas atau pekerjaan. Secara umum, kerangka teori dari penelitian ini diinformasikan oleh teori habitus yang dikembangkan oleh Pierre Bourdieu pada tahun 1984. Habitus dapat didefinisikan sebagai suatu sistem sosial dan budaya yang ditentukan melalui cara berpikir, persepsi, dan evaluasi yang diinternalisasi oleh individu.Habitus adalah pemindahan suatu sistem yang relatif stabil dimana individu mengintegrasikan pengalaman mereka dan mengevaluasi pentingnya pilihan sumber informasi yang berbeda, misalnya tentang preferensi sumber informasi dan saluran informasi.Habitus sendiri memiliki karakter ganda. Di satu sisi, hal tersebut dapat dilihat sebagai prinsip generatif terhadap penilaian obyektif yang dapat diklasifikasikan (habitus sebagai "struktur penataan" yang mengatur disposisi yang berbeda).

Di sisi lain, habitus dikatakan sebagai"struktur yang terstruktur" yakni sistem pengklasifikasian praktek-praktek dalam suatu kelompok masyarakat sesuai dengan nilai yang diterapkan dalam kelompok tersebut. Dalam peran ganda ini, habitus memanifestasi- 
Diterbitkan oleh Program Studi IImu Komunikasi

Universitas Ahmad Dahlan Yogyakarta

kan penggabungan norma dan harapan sosial pada individu. Sehingga habitus dapat dikatakan lebih dari sebuah agregasi disposisi pribadi yang "murni". Sebagai sistem yang ditentukan secara sosial dan budaya, disposisi habitus membentuk dasar pengaturan cara hidup seseorang.Habitus adalah sebuah konsep yang sangat abstrak yang berfungsi sebagai latar belakang umum untuk penelitian ini, konsep cara hidup diperkenalkan untuk menggambarkan perwujudan praktis dari habitus. Cara hidup yang terkait dengan konsep tentang penguasaan hidup adalah konteks dasar dimana masalah penemuan informasi non- pekerjaan akan dikaji. Hal ini menjadi bermasalah karena tidak ada konsensus di antara para peneliti mengenai definisi cara hidup.Perbedaan utama antara konsep- konsep ini adalah cara hidup dibentuk secara utama melalui kegiatan sehari-hari dan saling menilai. Sedangkan konsep gaya hidup yang utama mengacu pada unsur-unsur "permukaan" gaya hidup, misalnya konsumsi dan pakaian.

Hal tersebut menekankan kesukaan individu dalam analisis dari pilihan yang dibuat dalam kehidupan sehari-hari.Studi ini memandang cara hidup karena berkonsentrasi pada substansi pilihan yang dibuat dalam kehidupan sehari-hari yang memungkinkan ulasan pada determinan sosial dan budaya pada masyarakat. Dengan demikian, perhatian dapat diberikan kepada kedua elemen obyektif dan subyektif dalam konstitusi kehidupan seharihari.

Konsep cara hidup mengacu pada "Order of Things" atau "urutan hal - hal" yang didasarkan atas pilihan-pilihan yang dilakukan oleh individu dalam kehidupan sehari-hari. Suatu "Hal" berdiri untuk berbagai kegiatan yang terjadi di kehidupan sehari-hari, yakni tidak hanya bersifat pekerjaan tetapi tugas produktif lainnya seperti perawatan rumah tangga dan kegiatan sukarela atau hobi. Sedangkan "Order" merujuk pada sumber preferensi yang diberikan kepada kegiatan ini. Urutan hal - hal tersebut ditentukan pada kedua dasar obyektif dan subyektif. Contoh dari dasar obyektif adalah panjang hari kerja yang menentukan jumlah waktu luang sehari-hari, sedangkan persepsi cara yang paling menyenangkan untuk menghabiskan waktu luang mengacu subyektif dasar urutan hal. Dalam banyak kasus, urutan hal adalah konstelasi kerja yang relatif mapan dan kegiatan non pekerjaan yang terjadi selama berhari-hari atau berminggu-minggu, seseorang dengan mudah mengambil cara ini sebagai cara yang paling alami atau normal untuk mengatur kehidupan sehari-hari nya.

Sejalan dengan itu, seseorang memiliki "susunan kognitif" yang menunjukkan persepsi mereka tentang bagaimana sesuatu hal dapat disusun ketika mereka dalam keadaan "normal". Melalui pilihan mereka, orang telah praktis terlibat dalam urutan hal tertentu yang merupakan kepentingan mereka agar lebih bermakna. Orang mungkin melihat hal ini sebagai indikasi konservatisme yang melekat pada kehidupan sehari-hari, akan tetapi pada dasarnya tidak ada yang tidak wajar di dalamnya. Meskipun orang sering mencari variasi dalam hidup, terutama di waktu senggang, unsur-unsur rekreatif biasanya dicari dalam cara "yang dikelola" yakni perilaku yang benar-benar tak terkendali dan hanya untuk perubahan adalah sebuah pengecualian. Dengan demikian, tampak bahwa setidaknya secara implisit kebanyakan orang mencari hubungan internal hal-hal sehari-hari karena memberikan mereka kesempatan yang lebih baik untuk merencanakan pilihan mereka dan bertindak dengan penuh arti. 
Urutan hal-hal yang didefinisikan sebagai "Order of Things" membentu faktorfaktor cara hidup yang terdiri atas (1) Analisis struktur anggaran waktu, (2) Analisis model konsumsi barang dan jasa, (3) Analisis Hobi. Faktor-faktor tersebut mengarahkan kepada praktek perilaku penemuan informasi dalam kehidupan sehari-hari (Everyday Life Information Seeking - ELIS) dalam hal ini adalah penemuan informasi kelompok ulama. Faktor pertama, analisis struktur anggaran waktu dapat didefinisikan sebagai struktur yang digambarkan sebagai hubungan antara rutinitas kerja sehari-hari dan pemanfaatan waktu luang untuk kepentingan pencarian hal-hal agama. Faktor kedua, analisis model konsumsi barang dan jasa dapat didefinisikan sebagai gambaran yang menunjukkan tentang bagian dari jumlah uang yang dihabiskan oleh ulama untuk memperoleh barang dan jasa guna memenuhi keperluan pencarian hal-hal agama. Faktor ketiga, analisis hobi dapat didefinisikan sebagai sesuatu hal yang paling disenangi oleh seseorang untuk mengisi waktu luang dengan kegiatan pencarian hal-hal agama.

Kemudian faktor-faktor diatas tersebut menjadikan ulamauntuk mencari sumber informasi yang dibutuhkan dan segala sesuatu hal yang digunakan oleh ulamaguna memonitor peristiwa sehari-hari dan mencari informasi untuk memecahkan masalah tentang pencarian hal-hal agama. Pengelompokan model penemuan informasi seseorang yang terdapat dalam praktek perilaku penemuan sumber informasi dalam kehidupan sehari-hari (Everyday Life Information Seeking - ELIS) disebut dengan tipologi penguasaan hidup. Tipologi ini digunakan untuk memecahkan masalah atau menemukan informasi tentang pencarian hal-hal agama. Terdapat empat tipologi ideal dalam penguasaan hidup ulamas, antara lain: (1) Penguasaan Hidup Optimistis-Kognitif, (2) Penguasaan Hidup Pesimistis-Kognitif, (3) Penguasaan Hidup Defensif-Afektif, serta (4) Penguasaan Hidup Pesimistis-Afektif.

1. Penguasaan Hidup Optimistis-Kognitif (Optimistic-Cognitive mastery of life) Tipe penguasaan hidup optimistis-kognitif dalam konteks penemuan informasi ini ditandai dengan adanya ketergantungan kuat seorang ulamaterhadap sumber dan saluran informasi dengan pikiran positif serta dirinya sendiri mampu menemukan informasi terkait.

2. Penguasaan Hidup Pesimistis-Kognitif (Pessimistic-Cognitive mastery of life) Tipe penguasaan hidup pesimistis-kognitif dalam konteks penemuan informasi ini ditandai dengan pendekatan pemecahan masalah dengan cara yang kurang ambisius yang memungkinkan masalah tidak terselesaikan secara optimal.Jenis ini sedikit ragu-ragu dalam mencari informasi terkait.

3. Penguasaan Hidup Defensif-Afektif (Deffensive-Affective mastery of life) Tipe penguasaan hidup defensive-afektif dalam konteks penemuan informasi ini didasarkan pada pandangan ulamayang optimis tentang solvabilitas suatu masalah dengan cara memotivasi diri untuk tetap mencari informasi.

4. Penguasaan Hidup Pesimistis-Afektif (Pessimistic-Affective mastery of life). Tipe penguasaan hidup pesimistis-afektif dalam konteks penemuan informasi ini ditandai dengan ulamatidak bergantung pada kemampuannya sendiri untuk memecahkan masalah kehidupan sehari-hari. 
Diterbitkan oleh Program Studi Ilmu Komunikasi

Universitas Ahmad Dahlan Yogyakarta

Model ELIS oleh Savolainen dapat dilihat di bawah ini:

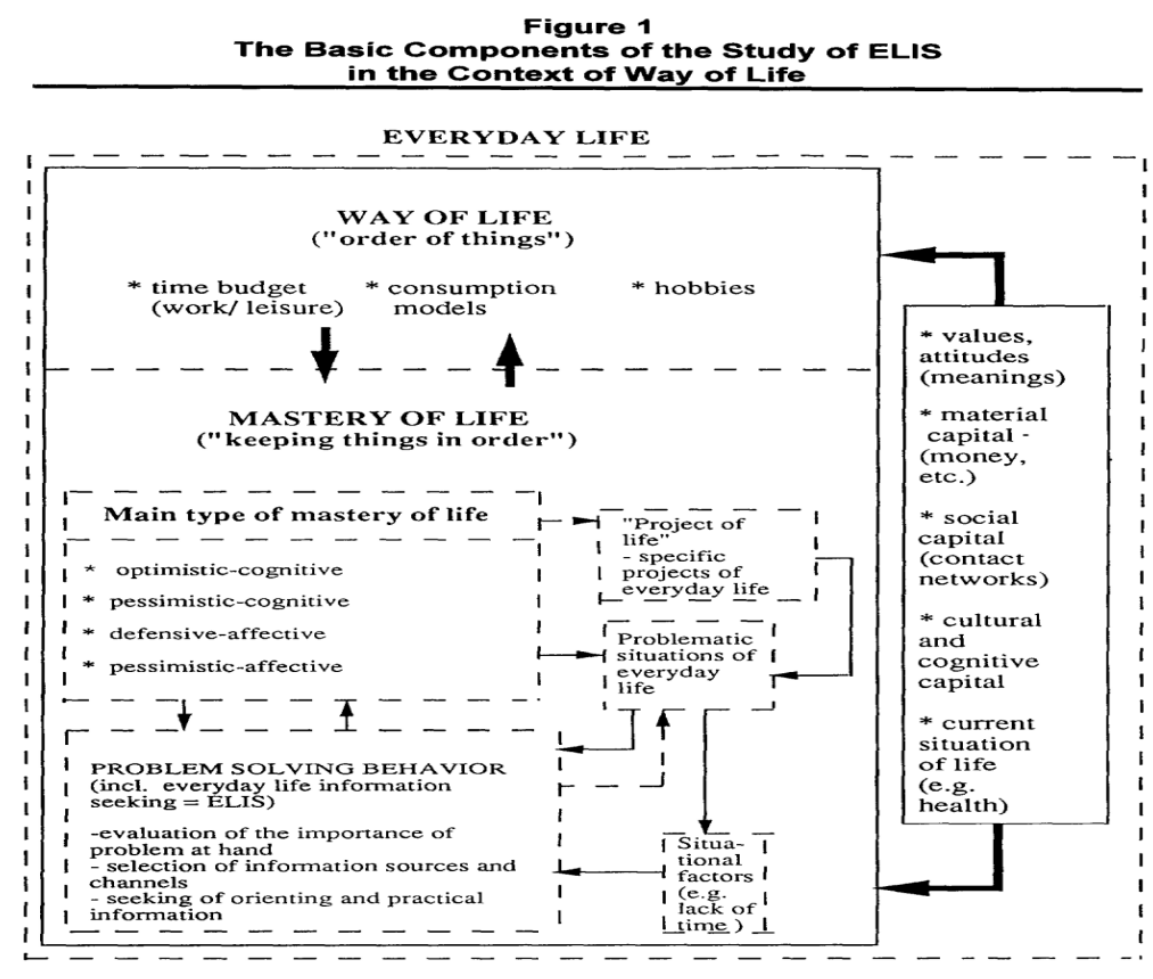

Terdapat variasi definisi informasi, untuk tujuan riset ini informasi dimaknai sebagai bagian dari proses komunikasi dimana individu menciptakan makna saat menjalani kesehariannya dan memahami kehidupan (McCready \& Rice in Case, 2007: 44-45). Terkait dengan ini adalah tipologi informasi yang diajukan oleh Brenda Dervin dengan mendasarkan pemikirannya pada filosofi Karl Popper (Case, 2007:43): a)objective, informasi eksternal yang menjelaskan tentang realitas; b) subjective, informasi yang berasal dari internal dimana individu memiliki peta kognitif tentang dunia kemudian merekatkannya pada realitas; c) sense-making, prosedur yang menjembatani informasi eksternal dan internal untuk memahami tentang dunia luar kemudian menggunakannya sebagi pijakan dalam mengambil tindakan.

Penelitian ini mengaitkan informasi dengan pemenuhan kebutuhan religius. Kebutuhan diartikan sebagai motivasi internal indvidu yang melatarbelakangi pikiran dan tindakan. Kebutuhan ditandai dengan adanya unsur instrumental seperti pencapaian tujuan, berbeda dengan keinginan, dan berkaitan dengan keperluan tertentu sebagai bagian dari pencapaian tujuan (Case, 2007, pp. 69-70).Di dalam karakterisasi ini, secara jelas bahwa kebutuhan merupakan kondisi internal yang terefleksikan dalam ekspresi-ekpresi yang kasat mata. Kebutuhan dalam pengertian sejenis ini menandakan bahwa individu menyadari ada keperluan yang dipuaskan dan secara aktif mencari hal yang bisa memenuhinya. 


\section{Konsep Ulama}

Konsep ulama' boleh ditakrif dengan berbagai difinasi yang berlandaskan latar belakang kesarjanaan atau disiplin ilmu masing-masing. Perkataan ulama' itu adalah kata jamak dari perkataan "'Arab iaitu 'Alim. Kemudian lahir pula perkataan "Alamah iaitu orang yang benar-benar mengerti atau mengetahui dengan mendalam hakikat sesuatu. (Muhamad Ismail, 1961:26.)

Menurut Dato' Dr. Harun Din, dalam al-Quran karim terdapat dua kali sahaja perkataan ulama' itu digunakan. Kedua-duanya merujuk kepada yang mendalami pengetahuan agama.Yang mendalami agama Islam diistilahkan dengan al-ulama'. Ada alif dan lam.Ini bererti bahawa ulama' adalah istilah khusus yang dimaklumi bahwa hanya diguna pakai untuk yang mengetahui dan mendalami tentang agama Islam saja. Apresiasi al-quran tidak hanya tergambar dari penyebutan kata 'a'lim dan derivasinya yang mencapai 823 kali, tetapi terdapat sekian ungkapan yang bermuara kesamaan makna seperti al-aql, al-fikr, alnazhr, al-basyar, al-tadabbur, al-'itibardan al-dzikr. Kata عالم alim yang juga merupakan akar kata dari ulama menurut pakar ahli al-quran Raghib al-ashfahani bermakna pengetahuan akan hakikat sesuatu. Dan علماء 'ulama adalah orang-orang yang punya ilmu. kata 'alim bermakna suatu pengaruh/bekas atau kemuliaan yang membedakannya dengan yang lain adapun kata ulama, dipahami sebagai orang yg memadukan pengetahuannya dengan pengamalannya.

\section{PROFIL MUHAMMADIYAH}

Berdirinya Muhammadiyah adalah karena alasan-alasan dan tujuan-tujuan sebagai berikut: (1) Membersihkan Islam di Indonesia dari pengaruh dan kebiasaan yang bukan Islam; (2) Reformulasi doktrin Islam dengan pandangan alam pikiran modern; (3) Reformulasi ajaran dan pendidikan Islam; dan (4) Mempertahankan Islam dari pengaruh dan serangan luar (H.A. Mukti Ali, dalam Sujarwanto dan Haedar Nashir, 1990: 332) dilansir pada web resmi muhammadiyah.

Penelitian James Peacock (1986: 26), seorang antropolog dari Amerika Serikat mengenai Muhammadiyah tahun 1970-an, mengungkapkan bahwa:'Dalam setengah abad sejak berkembangnya pembaharuan di Asia Tenggara, pergerakan itu tumbuh dengan cara yang berbeda di bermacam macam daerah. Hanya di Indonesia saja gerakan pembaharuan Muslimin itu menjadi kekuatan yang besar dan teratur. Pada permulaan abad ke-20 terdapat sejumlah pergerakan kecil kecil, pembaharuan di Indonesia bergabung menjadi beberapa gerakan kedaerahan dan sebuah pergerakan nasional yang tangguh, Muhammadiyah. Dengan beratus-ratus cabang di seluruh kepulauan dan berjuta-juta anggota yang tersebar di seluruh negeri, Muhammadiyah memang merupakan pergerakan Islam yang terkuat yang pernah ada di Asia Tenggara. Sebagai pergerakan yang memajukan ajaran Islam yang murni, Muhammadiyah juga telah memberikan sumbangan yang besar di bidang kemasyarakatan dan pendidikan. Klinik-klinik perawatan kesehatan, rumah-rumah piatu, panti asuhan, di samping beberapa ribu sekolah menjadikan Muhammadiyah sebagai lembaga non-Kristen dalam bidang kemasyarakatan, pendidikan dan keagamaan swasta yang utama di Indonesia. 'Aisyiah, organisasi wanitanya, mungkin merupakan pergerakan wanita Islam 
Diterbitkan oleh Program Studi IImu Komunikasi

Universitas Ahmad Dahlan Yogyakarta

yang terbesar di dunia. Pendek kata Muhammadiyah merupakan suatu organisasi yang utama dan terkuat di negara terbesar kelima di dunia." www.muhammadiyah.or.id

Islam tidak hanya ditampilkan secara otentik dengan jalan kembali kepada sumber ajaran yang aseli yakni Al-Qur'an dan Sunnah Nabi yang sahih, tetapi juga menjadi kekuatan untuk mengubah kehidupan manusia dari serba ketertinggalan menuju pada dunia kemajuan. Fenomena baru yang tampak menonjol dari kehadiran Muhammadiyah ialah, bahwa gerakan Islam yang murni dan berkemajuan itu dihadirkan bukan lewat jalur perorangan, tetapi melalui sebuah sistem organisasi. Menghadirkan gerakan Islam melalui organisasi merupakan terobosan waktu itu, ketika umat Islam masih dibingkai oleh kultur tradesional yang lebih mengandalkan kelompok-kelompok lokal seperti lembaga pesantren dengan peran kyai yang sangat dominan selaku pemimpin informal. Organisasi jelas merupakan fenomena modern abad ke-20, yang secara cerdas dan adaptif telah diambil oleh Kyai Dahlan sebagai "washilah" (alat, instrumen) untuk mewujudkan cita-cita Islam.

\section{PROFIL NAHDLATUL ULAMA}

Berdasarkan data dari website resmi nahdlatul ulama di www.nu.or.id, jumlah warga Nahdlatul Ulama (NU) diperkirakan mencapai lebih dari 40 juta orang, dari beragam profesi. Sebagian besar dari mereka adalah rakyat jelata, baik di kota maupun di desa. Mereka memiliki kohesifitas yang tinggi karena secara sosial-ekonomi memiliki masalah yang sama, selain itu mereka juga sangat menjiwai ajaran Ahlusunnah Wal Jamaah. Pada umumnya mereka memiliki ikatan cukup kuat dengan dunia pesantren yang merupakan pusat pendidikan rakyat dan cagar budaya NU.

Sejalan dengan pembangunan dan perkembangan industrialisasi. Warga NU di desa banyak yang bermigrasi ke kota memasuki sektor industri. Jika selama ini basis NU lebih kuat di sektor pertanian di pedesaan, maka saat ini, pada sektor perburuhan di perkotaan, juga cukup dominan. Demikian juga dengan terbukanya sistem pendidikan, basis intelektual dalam NU juga semakin meluas, sejalan dengan cepatnya mobilitas sosial yang terjadi selama ini. Nahdlatul Ulama (NU) menganut paham Ahlussunah Wal Jama'ah, sebuah pola pikir yang mengambil jalan tengah antara ekstrim aqli (rasionalis) dengan kaum ekstrim naqli (skripturalis). Karena itu sumber pemikiran bagi NU tidak hanya Al-Qur'an, Sunnah, tetapi juga menggunakan kemampuan akal ditambah dengan realitas empirik. Cara berpikir semacam itu dirujuk dari pemikir terdahulu, seperti Abu Hasan Al-Asy'ari dan Abu Mansur Al-Maturidi dalam bidang teologi. Kemudian dalam bidang fikih mengikuti empat Madzhab Hanafi, Maliki, Syafi'i, dan Hanbali. Sementara dalam bidang tasawuf, mengembangkan metode Al-Ghazali dan Junaid Al-Baghdadi, yang mengintegrasikan antara tasawuf dengan syariat.

Gagasan kembali ke Khittah pada tahun 1984, merupakan momentum penting untuk menafsirkan kembali ajaran Ahlussunnah Wal Jamaah, serta merumuskan kembali metode berpikir, baik dalam bidang fikih maupun sosial. Serta merumuskan kembali hubungan NU dengan negara. Gerakan tersebut berhasil membangkitkan kembali gairah pemikiran dan dinamika sosial dalam NU. 


\section{E. PEMBAHASAN}

Empat narasumber dalam penelitian ini yang menjadi pengamatan, kesemuanya berdomisili di Yogyakarta. Dua narasumber adalah pengurus dari PWNU DIY, dan untuk Muhammadiyah adalah pengurus Ranting di Yogyakarta. Kedua-duanya Pengamatan dan pendalaman yang dianalisa selama penelitian adalah faktor-faktor cara hidup habitus yang berperan ketika narasumberakan menemukan informasi, pengelolaan waktu mereka dalam mengatur kegiatan menemukan informasi yang dibutuhkan. Analisis struktur anggaran waktu yang digambarkan sebagai hubungan antara kerja dan waktu luang, dengan kata lain struktur ini mengungkapkan proporsi waktu yang dihabiskan untuk pekerjaan, kegiatan diluar pekerjaan seperti membaca, menonton bola, olahraga, traveling, dll. (Savolainen: 1995). Hasil wawancara dengan narasumber dapat diketahui bahwa narasumbermemiliki profesi dan beban kerja serta pembagian waktu antara rutinitas kerja dengan kegiatan yang berbeda-beda. Dua narasumber memiliki jumlah hari kerja 5 hari narasumber karena berstatus PNS dan hari masuk kerja atau kuliah Senin-Jumat. Sedangkan yang lainnya bekerja di swasta sehingga harus bekerja hingga Sabtu, tetapi itu semua tidak menjadi masalah bagi mereka dalam membagi waktu

Dalam menganalisis faktor model konsumsi barang dan jasa, seseorang dapat membuat gambaran yang menunjukkan bagian dari uang atau pendapatan yang dihabiskan untuk perolehan berbagai barang atau jasa untuk menunjang kepentingan sehari-hari seperti membeli buku, perlengkapan memasak. Dalam penelitian ini terdapat penjelasan mengenai pendapatan yang digunakan untuk kepentingan mencari informasi, misalnya membeli buku atau kitab, membeli perlengkapan untuk kepentingan dakwah. Berdasarkan temuan data terdapat indikator yang menjelaskan tentang jumlah penghasilan per bulan dan sumber pendapatan, serta jumlah konsumsi untuk kegiatan pencarian informasi yang sangat bervariasi. Untuk penggunaan gadget kebanyakan dari para narasumber ini hanya mempunyai satu smartphone untuk keperluan sehari-hari. Kebutuhan alat satu ini untuk membantu dalam mendapatkan informasi tentang keperluan materi-materi dalam mengisi kegiatan keagamaan. Juga untuk keperluan organisasi.

Sumber informasi yang dibutuhkan oleh narasumber guna penemuan informasi yang signifikan memberikan penjelasan tentang sumber-sumber informasi apa sajakah yang dibutuhkan oleh ulama agar menemukan informasi yang signifikan sesuai dengan kebutuhannya. Sumber-sumber informasi disini sangat berguna bagi para ulama untuk memecahkan masalah baik. Beberapa yang selalu dibuka adalah situs organisasi, dan materi yang seringkali acak, dicari di search engine seperti google.

Dalam Penguasaan Hidup Optimistis-Kognitif (Optimistic-Cognitive mastery of life). Tipe penguasaan hidup dalam konteks ini ditandai dengan adanya ketergantungan kuat seseorang pada hasil informasi yang positif untuk memecahkan masalah. Dalam pengamatan dan wawancara yang dilakukan ulama yang menjadi narasumber sebagian besar optimis memiliki keyakinan bahwa hasil yang diperoleh berdasarkan kemampuan atas kontrol dirinya sendiri. Sehingga dengan cara tersebut mereka merasa dapat mengantisipasi dan memilih hasil informasi terbaik yang pernah dialaminya. Selain itu narasumber memiliki pandangan relatif stabil dan memandang suatu kegagalan bersifat temporer dan spesifik sehingga tidak mempengaruhi hal lain dan menyalahkan diri sendiri. Sedangkan dalam pe- 
Diterbitkan oleh Program Studi IImu Komunikasi

Universitas Ahmad Dahlan Yogyakarta

mecahan masalah faktor kognitif lebih mendominasi dari narasumber dihasilkan ulama yang baik merujuk pada kecerdasan atau intelektualitas yang dimiliknya. Aspek kognitif memiliki domain antara lain: pengetahuan, pemahaman, penerapan, analisis, sintesa dan evaluasi. Seseorang yang memiliki tipe optimistis-kognitif percaya bahwa hampir semua masalah dapat diselesaikan dengan berfokus pada analisis rinci dan abstrak dari suatu informasi. Dalam penyelesaiannya terletak pada pemilihan instrument yang paling efektif dan akan berkontribusi optimal pada pemecahan masalah. Karena dalam konteks ini masalah dipahami sebagai kognitif, penemuan informasi yang sistematis dari sumber dan saluran diperlukan sangat berbeda-beda.

Dalam Penguasaan Hidup Pesimistis-Kognitif, Tipe penguasaan hidup pesimistiskognitif dalam konteks penemuan informasi ini ditandai dengan pendekatan pemecahan masalah dengan cara yang kurang ambisius yang memungkinkan masalah tidak terselesaikan secara optimal oleh narasumber. Dengan kata lain kemungkinan masalah tidak dapat diselesaikan secara optimal dikarenakan oleh pengetahuan yang dimiliki oleh individu masih kurang. Namun secara sistematis narasumber memerlukan informasi agar dapat memecahkan masalah yang sedang dihadapinya dengan menggunakan kecerdasan atau intelektualitasnya yang dapat dilihat dari aspek pengetahuan, pemahaman, penerapan, analisis, sintesa dan evaluasi. Apabila menghadapi suatu masalah narasumber dari NU sedikit raguragu dalam menemukan informasi terkait dengan pengalamannya mengaji karena pengalamannya menjadi ulama merasa masih kurang. Dengan kata lainnarasumber masih merasa ilmu yang digunakan dalam berdakwah masih banyak kurangnya, merasa belum menjadi ulama. Oleh karena itu dalam mencari dan menemukan informasi biasanya mereka bisa memperoleh sendiri namun masih membutuhkan bantuan orang lain untuk memastikan kebenaran dari informasi yang didapatkannya, termasuk strateginya dalam kegiatan mencari data-data.

Penguasaan Hidup Defensif-Afektif, Tipe penguasaan hidup dalam konteks ini didasarkan pada pandangan optimis tentang solvabilitas suatu masalah dan tetap bertahan dengan pandangannya tersebut. Dalam pemecahan masalah dan mencari informasi, faktor afektif lebih mendominasi yakni merujuk pada ranah emosi dan perasaan. Faktor afektif memiliki domain antara lain penerimaan, pemberian respon atau partisipasi, penilaian atau penentuan sikap, organisasi yang bertujuan untuk penyatuan nilai, dan karakteristik seseorang Dengan demikian narasumber dapat menghindari situasi yang menyiratkan risiko kegagalan dan memotivasi diri mencari informasi. Dalam ulama yang menjadi narasumber baik dari NU dan Muhammadiyah sangat memperhitungkan resiko yang terjadi sebelum dan saat perjalanan mencari data-data dilakukan. Narasumber sangat antusias melakukan kegiatan mencari data namun juga sangat perhitungan terutama berkaitan dengan resiko.

Penguasaan Hidup Pesimistis-Afektif, Tipe penguasaan hidup pesimistis-afektif dalam konteks penemuan informasi ini ditandai dengan narasumber tidak bergantung pada kemampuan sendiri untuk memecahkan masalah kehidupan sehari-hari, tetapi mengadopsi strategi dari ulama lain untuk menghindari upaya-upaya sistematis guna mendapatkan kesenangan instan dari hari ke hari yang memainkan peran reaksi emosional dan pengamatan pendek dalam penemuan informasi tentang mencari data. Ulama yang menjadi narasumber bersifat kritis, dengan kata lain dia melakukan pencarian informasi harus mengetahui isi 
yang terjadi dan informasi yang terkait dengan mencari data dan membanding-bandingkan dengan yang lain.

\section{F. SIMPULAN}

Dari hasil temuan data yang dihimpun berdasarkan pertanyaan dan pernyataan responder, peneliti dapat menarik kesimpulan bahwa Sebagian besar narasumberUlama NU maupun Muhammadiyah memperoleh sumber informasi dengan cara mengakses di media elektronik. Jenis sumber informasi yang sebagian besar sering diakses oleh ulama adalah media elektronik seperti website atau blog, televisi, dan medsos. Alasan pemilihan media elektronik sebagian besar narasumber adalah karena mudah dijangkau, nyaman, dan ekonomis sebagai seseorang yang waktunya sangat padat aktivitas. 
Diterbitkan oleh Program Studi Ilmu Komunikasi

Universitas Ahmad Dahlan Yogyakarta

\section{DAFTAR PUSTAKA}

Baillet, Patricia Olivia Covarrubias. (2009). Ethnography of Communication in Encyclopedia of Communication

McCready, Eric. 2007. In Proceedings of Japanese/Korean Linguistics .Sekkaku

McCready, Eric 2011. What is Evidence in Natural Language? Manuscript, Aoyama Gakuin University.

Scheibel, Dean. (2009). Qualitative, Ethnographic, and Performative Approaches to Communications in 21st Century Communication, A Reference Handbook edited by William F. Eadie, California, Sage Publication.

Moleong, Lexy J. (2010). Metodologi Penelitian Kualitatif, Bandung, Rosda

Popper, Karl, 2011. After 'The Open Society': Selected Social and Political Writings.London: Routledge,

Savolainen, Reijo. 1993. The sense-making theory: Reviewing the interests of a usercentered approach to information seeking and use. Information Processing and Management

Stephen W. Littlejohn and Karen A. Foss, Los Angeles. Human Communication Theory Edited Theory Sage Publications

\section{Website}

www.merdeka.com

www,muhammadiyah.or.id

www.nu.or.id 